\title{
Primary Intramedullary Langerhans Cell Histiocytosis of the Thoracic Spinal Cord -Case Report-
}

\author{
Toru YAMAGATA, ${ }^{1}$ Toshihiro TAKAMI, ${ }^{1}$ Naoki YAMAMOTO, ${ }^{1}$ \\ Sayaka TANAKA, ${ }^{2}$ Kenichi WAKASA, ${ }^{2}$ and Kenji OHATA ${ }^{1}$ \\ Departments of ${ }^{1}$ Neurosurgery and ${ }^{2}$ Diagnostic Pathology, \\ Osaka City University Graduate School of Medicine, Osaka, Osaka
}

\begin{abstract}
A 28-year-old male presented with a rare case of primary intramedullary spinal Langerhans cell histiocytosis (LCH) manifesting as the chief complaint of a 6-month history of gait disturbance and back pain, and difficulty with sphincter control. Serial $T_{2}$-weighted magnetic resonance imaging of the thoracic spine revealed enlargement and intramedullary hyperintensity of the spinal cord at T2 to T4. Biopsy of the lesion was performed. Histological examination of the biopsy specimens verified vascular proliferation and remarkable infiltration of histiocytes that were positive for CD1a, suggesting a diagnosis compatible with LCH. The patient was treated successfully by steroid pulse therapy. LCH is a rare disease that occurs mainly in children and may cause a broad range of manifestations, from a single osseous lesion to multiple lesions involving more than one organ or system. The present case illustrates the unexpected occurrence and important differential diagnosis of primary intramedullary spinal LCH of the thoracic spine in adult patients presenting with progressive paraparesis and back pain.
\end{abstract}

Key words: intramedullary histiocytosis, Langerhans cell histiocytosis, thoracic spine

\section{Introduction}

Langerhans cell histiocytosis (LCH) is a clonal proliferation of Langerhans cells occurring as an isolated lesion or as part of systemic proliferation. ${ }^{25,26)}$ The designation of LCH has now replaced the previous nomenclature of the group of diseases termed histiocytosis $\mathrm{X}$, eosinophilic granuloma of the bone, Hand-SchüllerChristian disease, or Letterer-Siwe disease. ${ }^{15)}$ The etiology of the tumor is still controversial,13,14,16,25,26) although clonal proliferation ${ }^{25,26)}$ or viral etiology ${ }^{13,16)}$ have been proposed. LCH most commonly occurs in the first two decades of life, as $80 \%$ of the patients are younger than 10 years old ${ }^{13,14,16,21)}$ and most patients are males. ${ }^{2,16)}$ The diagnosis of LCH in adults is rare. ${ }^{14,16,21)}$ The clinical manifestations and course are highly variable, and range from a self-healing solitary lesion to fatal, multi-organ involvement. LCH is classified into three distinct types: single-system single site (SS-s), single-system multisites (SS$\mathrm{m}$ ), and multisystem (MS). An epidemiological study in Japan has reported that the SS-s, SS-m, and MS types of $\mathrm{LCH}$ are diagnosed at a ratio of almost $1: 1: 1 .^{12)} \mathrm{LCH}$ is known to involve many tissues including the central nervous system. Brain involvement most commonly occurs by contiguous spread from the cranium and sinuses. ${ }^{3,4,17)}$ Spinal cord involvement is rare, and usually occurs by

Received February 18, 2012; Accepted May 9, 2012 direct extension from the surrounding bone tissue, but may also arise as metastatic spread from other tissues. $1,5,8,9,11,15,17,20,22,24,27)$ Isolated extramedullary or intramedullary lesion of the spinal cord is extremely rare. ${ }^{10,24)}$ We report an extremely rare case of primary intramedullary spinal LCH of the thoracic spine.

\section{Case Report}

A 28-year-old male was admitted with the chief complaint of a 6-month history of gait disturbance and back pain. $\mathrm{He}$ also had difficulty with sphincter control. Neurological examination on admission showed spastic mild paraparesis, mild hypalgesia, and decreased deep sensation on the right lower extremity. Laboratory investigations did not suggest any possibility of spinal inflammatory disease. $\mathrm{T}_{2^{-}}$ weighted magnetic resonance (MR) imaging of the thoracic spine revealed enlargement and intramedullary hyperintensity of the spinal cord at $\mathrm{T} 2$ to $\mathrm{T} 4$. These changes in $\mathrm{MR}$ images apparently progressed over one month (Fig. 1A, B). $\mathrm{T}_{1}$-weighted $\mathrm{MR}$ images with contrast medium showed increased intensity within the dorsolateral aspect of the spinal cord at T3 (Fig. 1C). No lesions or involvement of the adjacent tissues was noted. Radiography and computed tomography, including the cervical spine and chest, detected no abnormalities.

The patient underwent a T3 to T5 osteoplastic laminotomy for partial resection of the tumor. The spinal 

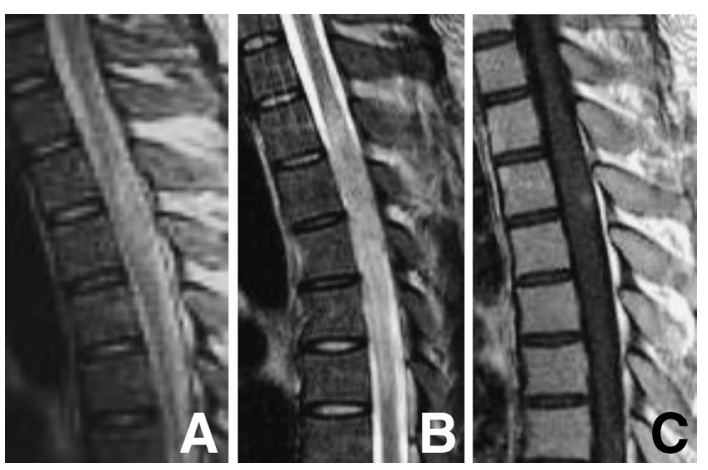

Fig. 1 A, B: Serial $T_{2}$-weighted magnetic resonance (MR) images showing enlargement and intramedullary hyperintensity of the spinal cord at T2 to T4 (B), which appeared to be apparently progressive compared to the images obtained one month before (A). C: $T_{1}$-weighted MR image with contrast medium showing increased intensity within the dorsolateral aspect of the spinal cord at $\mathrm{T} 3$.
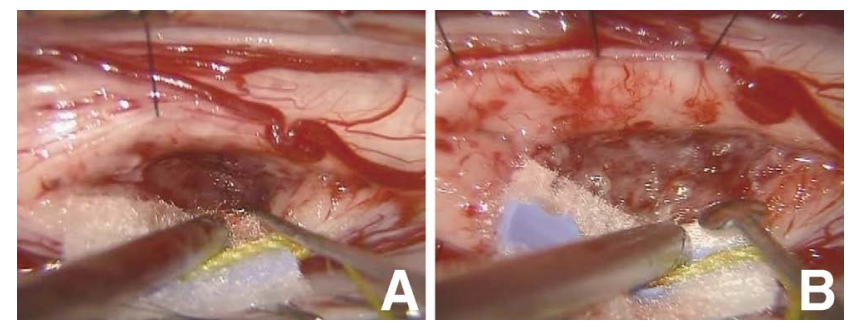

Fig. 2 Intraoperative photographs showing that the spinal cord appeared swollen (A), and after posterior midline myelotomy of the spinal cord the gray soft tumor was revealed without a clear margin with the spinal cord tissue (B).

cord appeared swollen (Fig. 2A). Posterior midline myelotomy of the spinal cord revealed the gray soft tumor without a clear margin with the spinal cord tissue (Fig. 2B), so only biopsy of the tumor was performed. Frozensection examination of the biopsy specimens revealed invasion of inflammatory cells, but not suggesting anaplastic nature of the tumor. Histological examination of the biopsy specimens verified vascular proliferation and remarkable infiltration of histiocytes that were positive for CD1a, suggesting a diagnosis compatible with LCH (Fig. 3).

Fluorine-18 fluorodeoxyglucose positron emission tomography $\left(\left[{ }^{18} \mathrm{~F}\right] \mathrm{FDG}-\mathrm{PET}\right)$ and technetium-99 scintigraphy of the whole skeleton showed no other lesion. Following steroid pulse treatment, MR imaging revealed remarkable improvement of the enlargement and intramedullary hyperintensity of the spinal cord (Fig. 4A). $\left[{ }^{18} \mathrm{~F}\right]$ FDG-PET, obtained 3 months after the surgery, showed abnormal accumulation of FDG in the left lung, suggesting a possible diagnosis of lung LCH. Cessation of smoking resulted in disappearance of the lesion in the lung. The patient's neurological condition 12 months after surgery was stable but not significantly different than be-
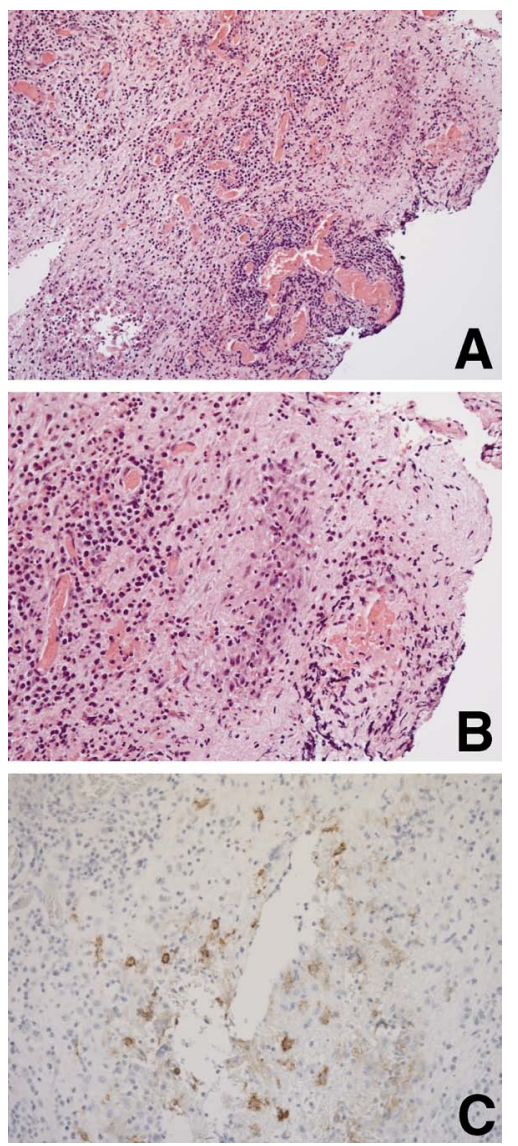

Fig. 3 Photomicrographs showing the characteristic features of Langerhans cell histiocytosis. Hematoxylin and eosin stain, original magnifications $\times 100(A), \times 200(B)$. Immunostain for CD1a, original magnification $\times 200(C)$.
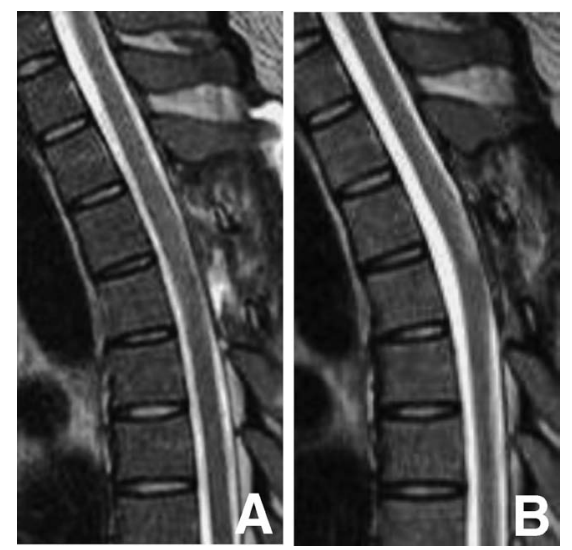

Fig. $4 \quad T_{2}$-weighted magnetic resonance images obtained at 3 months (A) and 1 year (B) after steroid pulse treatment revealing remarkable improvement of the enlargement and intramedullary hyperintensity of the spinal cord.

fore surgery, and no recurrence was noted (Fig. 4B). 
Table 1 Cases of primary extramedullary or intramedullary spinal Langerhans cell histiocytosis

\begin{tabular}{|c|c|c|c|c|c|c|c|c|c|c|}
\hline Author (Year) & $\begin{array}{l}\text { Age } \\
\text { (yrs) }\end{array}$ & Sex & $\begin{array}{l}\text { Location } \\
\text { and type }\end{array}$ & Surgery & Steroid & Chemotherapy & Radiotherapy & $\begin{array}{l}\text { Recurrence or } \\
\text { reactivation }\end{array}$ & Outcome & $\begin{array}{l}\text { Follow-up } \\
\text { (mos) }\end{array}$ \\
\hline $\begin{array}{l}\text { Whelan et al. } \\
(1987)^{24)}\end{array}$ & 1 & M & $\begin{array}{l}\text { C2-C4, EM, } \\
\text { SS-s }\end{array}$ & subtotal & preop & - & 7.5 Gy, local & - & improved & 18 \\
\hline Present case & 28 & M & $\begin{array}{l}\text { T3, IM, } \\
\text { SS-s }\end{array}$ & biopsy & postop & - & - & lung? & stable & 12 \\
\hline
\end{tabular}

EM: extramedullary, IM: intramedullary, postop: postoperative, preop: preoperative, MM: multisystem, SS-s: single-system single site.

\section{Discussion}

Isolated extramedullary or intramedullary lesion of the spinal cord is extremely rare (Table 1). ${ }^{10,24)}$ The first case of isolated LCH occurred exclusively in the spinal cord of the cervical spine. ${ }^{24)}$ The entire lesion was clearly visible on MR imaging of the spinal cord. Surgical verification of the tumor confirmed the extramedullary location of the LCH. The extramedullary spinal LCH was treated with local low-dose radiation which resulted in complete regression. Another extremely rare case was intramedullary spinal LCH of the cervical spine. ${ }^{10)}$ MR imaging of the spinal cord clearly demonstrated enlargement of the spinal cord with abnormal enhancement. Surgical verification of the tumor demonstrated the intramedullary location of the $\mathrm{LCH}$, but no clear dissection plane was visible. The intramedullary spinal LCH was treated with local low-dose radiation, which resulted in gradual regression at 1-year follow up.

Several clinical studies have been performed to clarify the outcome of $\mathrm{LCH}$, including the international clinical trials of the Histiocyte Society ${ }^{6,7)}$ and a clinical study of the Japan LCH Study Group. ${ }^{18)}$ However, there is no standard treatment for SS-s-type LCH. To date, only two studies have examined a large number of patients with singlesystem LCH. ${ }^{18,23)}$ The prognosis of patients with SS-s-type LCH is generally good, so chemotherapy is not commonly prescribed. The DAL-HX 83/90 study reported that a response to initial therapy was seen in all SS-s patients and $18 \%$ of them experienced reactivation. ${ }^{23)}$ Response to initial therapy was seen in $99.3 \%$ of SS-s patients and $7 \%$ of those patients experienced reactivation. ${ }^{19)}$ The present case may be comparable to SS-s, and requires careful follow-up.

The long-term overall outcome of spinal LCH is still unclear and may not be entirely optimistic. This present extremely rare case of intramedullary spinal LCH of the thoracic spine illustrates the unexpected occurrence and important differential diagnosis in an adult patient presenting with progressive paraparesis and back pain. Multidisciplinary treatment should be standard, but further clinical investigation is required.

\section{Conflicts of Interest Disclosure}

The authors report no conflict of interest concerning the materials or methods used in this study or the findings specified in this paper. All authors who are members of The Japan Neurosurgical Society (JNS) have registered online Self-reported COI Disclosure Statement Forms through the website for JNS members.

\section{References}

1) Al-Rodhan NRF, Al-Mefty O, Godwin JT, Jinkins JR, Fox JL: Histiocytosis-X of the spinal cord: a case report. Neurosurgery 19: 837-840, 1986

2) Azouz EM, Saigal G, Rodriguez MM, Podda A: Langerhans' cell histiocytosis: Pathology, imaging and treatment of skeletal involvement. Pediatr Radiol 35: 103-115, 2005

3) Beard W, Foster DB, Kepes JJ, Guillan RA: Xanthomatosis of the central nervous system. Clinical and pathological observations of a case with a posterior fossa syndrome. Neurology 20: 305-314, 1970

4) Feigin I: Xanthomatosis of the nervous system. J Neuropathol Exp Neurol 15: 400-416, 1956

5) Ferris RA, Pettrone FA, McKelvie AM, Twigg HL, Chun BK: Eosinophilic granuloma of the spine: An unusual radiographic presentation. Clin Orthop 99: 57-63, 1974

6) Gadner H, Grois N, Arico M, Broadbent V, Ceci A, Jakobson A, Komp D, Michaelis J, Nicholson S, Pötschger U, Pritchard J, Ladisch S: A randomized trial of treatment for multisystem Langerhans' cell histiocytosis. J Pediatr 138: 728-734, 2001

7) Gadner H, Grois N, Pötschger U, Minkov M, Aricò M, Braier J, Broadbent V, Donadieu J, Henter JI, McCarter R, Ladisch S: Improved outcome in multisystem Langerhans cell histiocytosis is associated with therapy intensification. Blood 111: 2556-2562, 2008

8) Gandolfi A: Vertebral histiocytosis-X causing spinal cord compression. Surg Neurol 19: 369-372, 1983

9) Groopman JE, Golde DW: The histiocytic disorders: a pathophysiological analysis. Ann Intern Med 94: 95-107, 1981

10) Hamilton B, Connolly ES, Mitchell WT Jr: Isolated intramedullary histiocytosis-X of the cervical spinal cord. Case report. J Neurosurg 83: 716-718, 1995

11) Hewlett RH, Ganz JC: Histiocytosis $X$ of the cauda equina. Neurology 26: 472-476, 1976

12) Imashuku S, Ikushima S, Hibi S, Todo S: Langerhans cell histiocytosis and hemophagocytic syndrome in Japan; epidemiological studies. Int J Hematol Oncol 1: 241-246, 1994

13) Kilborn TN, Teh J, Goodman TR: Paediatric manifestations of Langerhans cell histiocytosis: A review of the clinical and radiological findings. Clin Radiol 58: 269-278, 2003

14) Kilpatrick SE, Wenger DE, Gilchrist GS, Shives TC, Wollan 
PC, Unni KK: Langerhans' cell histiocytosis (histiocytosis X) of bone. A clinicopathologic analysis of 263 pediatric and adult cases. Cancer 76: 2471-2484, 1995

15) Lichtenstein L: Histiocytosis X; integration of eosinophilic granuloma of bone, "Letterer-Siwe disease," and "SchüllerChristian disease" as related manifestations of a single nosologic entity. Arch Pathol 56: 84-102, 1953

16) Lieberman PH, Jones CR, Steinman RM, Erlandson RA, Smith J, Gee T, Huvos A, Garin-Chesa P, Filippa DA, Urmacher C, Gangi MD, Sperber M: Langerhans cell (eosinophilic) granulomatosis. A clinicopathologic study encompassing 50 years. Am J Surg Pathol 20: 519-552, 1996

17) Miller AA, Ramsden F: Neural and visceral xanthomatosis in adults. J Clin Pathol 18: 622-635, 1965

18) Morimoto A, Ikushima S, Kinugawa N, Ishii E, Kohdera U, Sako M, Fujimoto J, Bessho F, Horibe K, Tsunematsu Y, Imashuku S: Improved outcome in the treatment of pediatric multifocal Langerhans cell histiocytosis: Results from the Japan Langerhans Cell Histiocytosis Study Group-96 protocol study. Cancer 107: 613-619, 2006

19) Morimoto A, Ishida $Y$, Suzuki N, Ohga S, Shioda $Y$, Okimoto Y, Kudo K, Ishii E; HLH/LCH Committee of the Japanese Society of Pediatric Hematology: Nationwide survey of singlesystem single site Langerhans cell histiocytosis in Japan. Pediatr Blood Cancer 54: 98-102, 2010

20) Salcman M, Quest DO, Mount LA: Histiocytosis-x of the spinal cord. Case report. J Neurosurg 41: 383-386, 1974

21) Simanski C, Bouillon B, Brockmann M, Tiling T: The Langerhans' cell histiocytosis (eosinophilic granuloma) of the cer- vical spine: A rare diagnosis of cervical pain. Magn Reson Imaging 22: 589-594, 2004

22) Sweasey TA, Dauser RC: Eosinophilic granuloma of the cervicothoracic junction. Case report. J Neurosurg 71: 942-944, 1989

23) Titgemeyer C, Grois N, Minkov M, Flucher-Wolfram B, Gatterer-Menz I, Gardner H: Pattern and course of singlesystem disease in Langerhans cell histiocytosis data from the DAL-HX 83- and 90-study. Med Pediatr Oncol 37: 108-114, 2001

24) Whelan HT, Clinton ME, Fogo A, Smith H: Histiocytosis- $X$ isolated to the cervical spinal cord. Am J Pediatr Hematol Oncol 9: 228-232, 1987

25) Willman CL: Detection of clonal histiocytes in Langerhans cell histiocytosis: biology and clinical significance. Br J Cancer Suppl 23: S29-33, 1994

26) Willman CL, Busque L, Griffith BB, Favara BE, McClain KL, Duncan MH, Gilliland DG: Langerhans'-cell histiocytosis (histiocytosis X)—a clonal proliferative disease. N Engl J Med 331: 154-160, 1994

27) Wroble RR, Weinstein SL: Histiocytosis $X$ with scoliosis and osteolysis. J Pediatr Orthop 8: 213-218, 1988

Address reprint requests to: Toshihiro Takami, MD, Department of Neurosurgery, Osaka City University Graduate School of Medicine, 1-4-3 Asahi-machi, Abeno-ku, Osaka 545-8585, Japan.

e-mail: ttakami@med.osaka-cu.ac.jp 